Seka Brkljača

\title{
KRLEŽA, HRVATI I SRBI ${ }^{1}$
}

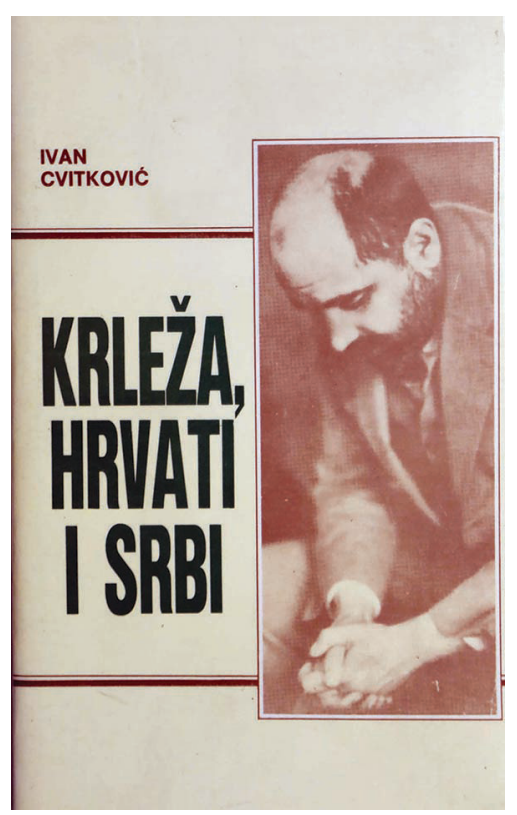

Mada ni u jednom svom djelu Miroslav Krleža nije eksplicite pisao o naciji, nacionalnostima, nacionalizmu, kompleksna problematika nacionalnog pitanja i nacionalnih odnosa, a kako bi i sam znao reći, trajno ga je zaokupljala, prateći i prožimajući gotovo sve njegove radove, još od 1916. godine. Krležina razmišljanja o nacionalnom pitanju nisu sveobuhvatna samo po tome što se dotiče gotovo svih naših nacija i nacionalnih sredina, nego i po širokoj lepezi obuhvaćenih problema, kao i raznovrsnih aspekata koji su proizilazili iz pristupa mnogim pitanjima istorije jugoslovenskih naroda, kao i pojava i događaja u nacionalnoj sferi. Krleža se prema mnogim ovim pitanjima odnosio krajnje direktno, beskompromisno, imenujući pojave i stvari njihovim makar i metaforično iskazanim imenom, svidjelo se to nekome ili ne. Konzekvence takvog Krležinog duha i takvog njegovog pristupa i odnosa prema pojedinim problemima naše dalje prošlosti, kao i onovremene stvarnosti, bile su da se za života naslušao kritika, koje ga nisu mimoišle ni nakon njegove fizičke smrti. Te kritike osobene su po potpuno protivrječnim ocjenama i to je njihova jedina zajednička karakteristika. Istovremeno je znao biti optuživan da je srbofil, unitarist, narodno i politički sumnjiva ličnost, pesimist, malograđanin, kalemljen mu je šovinizam, nacionalizam, s druge strane smatran je frankovcem i ustašom, za ustaše je opet bio marksist i komunist, dok je za pojedine marksiste predstavljao salonskog komunistu, koji se nije priključio narodnooslobodilačkom pokretu, za klerikalce bio je antikrist, luteran, sotona. Istovremeno optuživan je da je i jedno i drugo i treće, što sve

${ }^{1}$ Prikaz knjige Krleža, Hrvati i Srbi. Prilozi, Institut za istoriju, Sarajevo, br. 27 (91), str. 248-249. 
zasigurno nije mogao biti istovremeno. Naravno, ovakve ocjene Krleža nije prihvatao mirno i stoički, odgovarao je nekada žestoko i dramatično, nekada u ispovjednom tonu, odbacujući prigovore i s jedne i s druge strane i tvrdeći 1934. godine da je sam. Krleža je zapravo branio pravo na misao, svoju misao, a u suštini, to je bio permanentan sukob stvaralačke individualnosti sa svojim okruženjem. To okruženje je posebno senzibilno na sva pitanja iz sfere nacionalne problematike te su takve oprečne kritike koje su upućivane Krleži proizilazile iz široke lepeze poimanja, shvaćanja i ubjeđenja šta je to nacionalna pripadnost, šta je uslovljava, određuje i karakteriše i koji su parametri naspram kojih se "mjeri" vrijednost i veličina pojedinih nacija, kao i pojedinih pripadnika unutar same nacije. U tom kontekstu treba posmatrati Krležin gotovo rezignirajući usklik 1977. godine o prokletom fantomu od nacije čije je prevladavanje za Krležu najosnovniji zadatak vremena.

Kome vjerovati u ovoj polarizaciji zagovarača krajnje oprečnih pozicija i teza? Puštajući samoga Krležu da govori Ivan Cvitković ovom knjigom se vraća na za nas uvijek krajnje osjetljivu i kompleksnu temu nacija-nacionalizam, davajući doprinos odstranjivanju sveg onog taloga i svega onoga što je pokušaj iskrivljavanja Krležinog života i njegovog djela. Istovremeno, omogućavajući da se Krleža pokaže u svom punom ljudskom i književnom liku velikog mislioca, Cvitković, bez intencija da se odredi kao krležijanac, odnosno antikrležijanac, svojom interpretacijom slijedi izvornu Krležinu misao neopterećenu jednostranošću, ideološkim zamraćenjima i logikom trenutnog ličnog interesa.

Možda je "vječito" hrvatsko-srpsko, odnosno srpsko-hrvatsko pitanje bilo i presudno da Miroslav Krleža, poslije Hrvata, ni o jednom narodu nije toliko pisao koliko o Srbima. Možda je to određenje uticalo i na Ivana Cvitkovića da ovako naslovi svoju knjigu. Međutim, iza naslova, kroz sadržaj u samoj knjizi ne nalazi se samo to određenje, niti izdvojeno samo to pitanje iz čitavog korpusa Krležinih misli o nacionalnom pitanju. Sam sadržaj knjige prevazilazi svoj naslov, potvrđujući nemogućnost posmatranja nacije kao zatvorene autarhične cjeline, bez korelativnog suodnosa sa drugima, kao i unutar same sebe u datom vremenu i prostoru. Temeljito upoznavajući i proučavajući Krležinu misao koja provejava kroz njegove drame, romane, eseje, kao i natpise u novinama i razgovore sa Enesom Čengićem itd., kao i konsultujući relevantnu filozofsku i sociološko-politološku, kao i književnokritičku literaturu, Ivan Cvitković je konstruisao neophodan kostur ove knjige u vidu tematskih poglavlja. U njima svojom interpretacijom slijedi izvornu Krležinu misao kojom oblači uspostavljeni kostur tematskih cjelina koji je i sam posljedica bogatstva Krležinog duha. Oprezno, ne podređujući Krležu nekoj svojoj una- 
prijed zadatoj tezi u predubjeđenju, Cvitković omogućuje da se Krleža pokaže u sferi nacionalnoga, i to u okviru tema kojima su naslovljena poglavlja knjige: Krležino određenje pojma naroda, Uloga jezika u konstituisanju nacije, Krleža o odnosu religija - religijska zajednica - nacija, Hrvatska i Hrvati, Hrvatska nacionalna svijest, O hrvatskoj malograđanštini, O hrvatskoj inteligenciji, Hrvati i Austro-Ugarska, O hrvatskom nacionalizmu, Hrvati $i$ Srbi, Krleža o Srbima, O Kosovu i Makedoniji, O ujedinjenju južnoslovenskih zemalja, O jugoslavenstvu, O nacionalizmu, Krleža o avnojskoj Jugoslaviji.

Ovakvim metodološkim pristupom Ivan Cvitković je do punog izražaja doveo Krležine stavove iz sfere nacionalnog u vremenu kada su izrečeni, prepuštajući čitaočevoj zrelosti da sam donosi zaključke. Istovremeno, na taj način Cvitković stvara pretpostavke za konstatiranje istorijskog stanja svijesti, posebno vrijednog u mogućoj komparaciji sa vremenom današnjim, jer nacija se razvija i nije nešto što će i u budućnosti ostati neizmijenjeno. Nacija za Krležu ne predstavlja neku statičku konstrukciju, niti konstantu, "ni kabinetski profilirani fantom", već se trajno mijenja i više je nalik na "korablju na talasima nego na solidnu zgradu sa nepokretnim temeljima".

Knjiga Ivana Cvitkovića obogaćena je registrom imena i pojmova, ali, na žalost, izostao je popis literature, najavljen u sadržaju knjige. Tu manjkavost čitalac može prevazići nalazeći neophodne podatke u dosta brojno bogatim napomenama, posebno vrijednim kada se radi o raznim pojmovima i pojašnjenjima, ali neprimjereno nivelirane količinom podataka kada su u pitanju poedine ličnosti koje se pominju u osnovnom tekstu knjige. 